doi: $10.5937 /$ SelSem1801011M

\title{
ISTA PROFICIENCY TEST 17-2 GERMINATION RESULTS OF WHITE CLOVER SEED
}

\author{
Marija Milivojević ${ }^{*}$, Jasna Kojić1, Radmila Vukadinović ${ }^{1}$, \\ Rade Stanisavljević2 , Dobrivoj Poštić ${ }^{2}$, Tanja Petrović
}

\begin{abstract}
The presence of hard seeds as a result of water impermeable seed coat is common in species of Fabaceae family. For wild plants, this characteristic allows better survival, but for agriculture production, hard seeds are undesirable, due to delayed and uneven germination. In seed testing laboratory several pre-treatments (pre-chill, mechanical scarification) can be applied for germination testing of these species. In this paper, Proficiency test 17-2 germination results of Trifolium repens seeds conducted in 150 laboratories around the world are presented. Those tests are organized by the International Seed Testing Association (ISTA) and are mandatory for all accredited laboratories. In this way laboratory's competence (staff, apparatus, test methods) is checked. In August 2017, samples of three Trifolium repens seed lots were distributed. In the Seed Testing Laboratory at the Maize Research Institute Zemun Polje (LIZP), germination was tested in September using mechanical scarification and pre-chilling ( 2 days at $5-10^{\circ} \mathrm{C}$ ) prior to germination at $20^{\circ} \mathrm{C}$. Among 90 accredited participants, only one more laboratory applied mechanical scarification, 42 laboratories did not use any pre-treatment, and 39 laboratories applied pre-chilling. Obtained germination results in LIZP (Lot1-84.50\%, Lot2-84\%, Lot3-88.50\%) were higher than overall mean (Lot1-76.95\%, Lot2-79.63\%, and Lot3-83.27\%). The main conclusion of this Proficiency test is that seed scarification significantly reduced the number of hard seeds in favour of normal seedlings. The reason for the rare application of scarification may be the requirement of the applicant to obtain adequate information regarding the number of hard seeds that will appear during seed sowing.
\end{abstract}

Key words: Trifolium repens, hard seeds, scarification

Original Scientific Paper (Originalni naučni rad)

${ }^{1}$ Milivojević M, Kojić J, Vukadinović R, Petrović T, Maize Research Institute „Zemun Polje“, Slobodana Bajića 1, Belgrade, Serbia

${ }^{2}$ Stanisavljević R, Poštić M, Institute for plant protection and environment, Teodora Drajzera 9, 11000 Belgrade, Serbia

*e-mail: mmarija@mrizp.rs 


\section{Introduction}

The presence of hard seeds as a result of water impermeable seed coat is common in species of Fabaceae family (Baskin and Baskin, 2014). For wild plants, this characteristic allows better survival, but for agriculture production hard seeds are undesirable, due to delayed and uneven germination. Research on viability and germination of Trifolium repens seeds has shown that physiological maturity is developed 12 days after pollination, while hardseededness starts to develop about 2 days later (Baskin and Baskin, 2014). In Trifolium species, hard seeds contain more polyphenols, lignin, tannin, cellulose pectin and hemicelluloses compared to seeds with permeable seed coat (Galussi and Moya, 2017). The portion of hard seed in legumes can be very high, ranging from 57 to $89 \%$ as shown by Uzun and Aydin, (2004). Investigations of effect of sowing densities on yield and quality of alfalfa seed revealed that presence of hard seeds are reduced with greater inter-row distance (Beković et al., 2008).

For agricultural production very important is to know the precise seed germination, so during calculations of seed quantity hard seeds can be taken into account. Hard seeds fail to germinate because of an impermeable outer seed coat which may be easily overcome by scarification or acid treatment (Kimura and Islam, 2012). In seed testing laboratory several pre-treatments (pre-chill, mechanical and acid scarification) can be applied for germination testing of these species (ISTA Rules, 2017).

The aim of this study was to present current methods used in the testing seed of white clover in laboratories worldwide and discuss about the way of reporting testing results on certificates for national and international trade. In this paper, Proficiency test (PT) 17-2 germination results of Trifolium repens seeds conducted in 150 laboratories around the world are presented.

\section{Material and method}

Proficiency tests which are organized by the International Seed Testing Association (ISTA) are mandatory for all accredited laboratories and voluntary for non-accredited laboratories. In this way laboratory's competence (staff, apparatus and test methods) is checked. In August 2017, ISTA Secretariat distributed samples of three Trifolium repens seed lots to 150 participants (90 accredited laboratories and 60 voluntary participants). Samples of different seed quality levels are selected based on preliminary test results. The seed lots selected for the PT must fulfill conditions of homogeneity (i.e. replications in the germination test must be within tolerance). In the Seed Testing Laboratory at the Maize Research Institute Zemun Polje (LIZP), germination was tested in September applying mechanical scarification and pre-chilling (2 days at $5-10^{\circ} \mathrm{C}$ ) prior to germination at $20^{\circ} \mathrm{C}$. LIZP is conducting mechanical scarification by mixing seeds with fine sand, pouring into the mortar, and gentle stirring with the pestle for 30-60 seconds and separating seeds from sand by sieving (Fig. 1).

The germination results are statistically analyzed using the publicly available and free " $\mathrm{R}$ " program. The principle of the method is to calculate $\mathrm{Z}$-scores $\left(\mathrm{Z}_{i}=\left(\mathrm{X}_{i}-\mathrm{X}\right) / \mathrm{S}\right)$ based on determining the true value represented by the estimated mean, after outliers have been eliminated. The in-round rating system for germination is based on the sum of absolute Z-scores. The laboratory's mean $\left(x_{i}\right)$ is correlated with the overall mean $(x)$, the estimated 'true value' of the sample, and the standard deviation (s) derived from the data of the accredited laboratories only, according the given formula. Only normal seedlings 


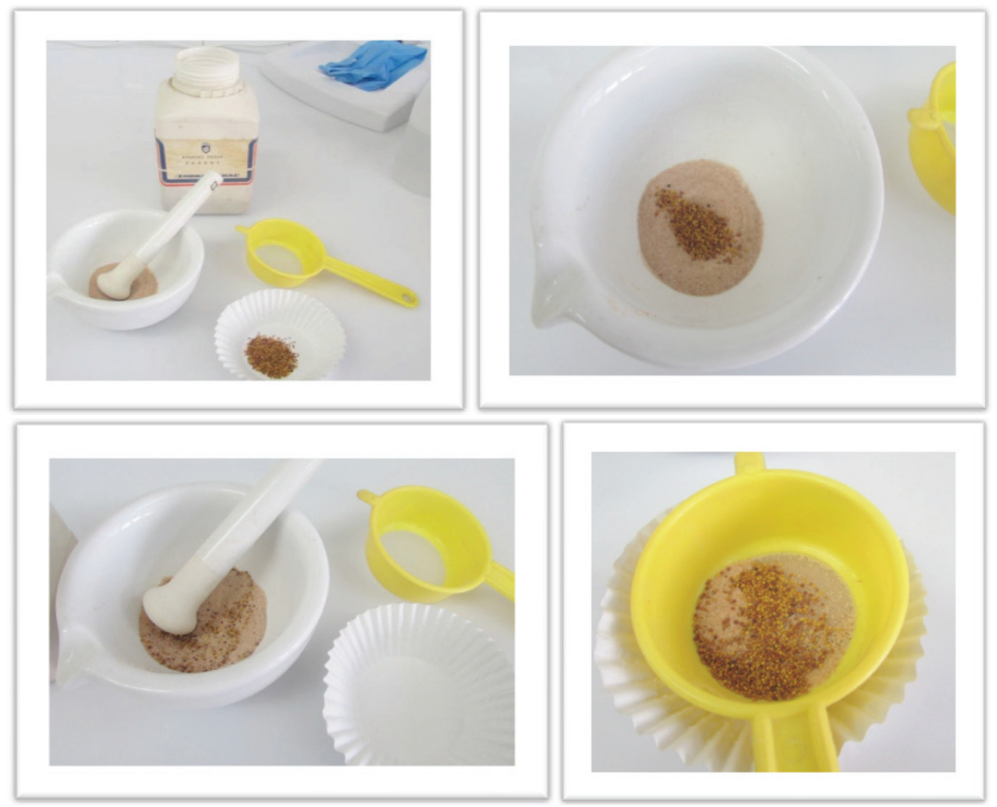

Figure 1 Procedure of mechanical scarification of seeds in LIZP Slika 1. Postupak mehaničke skarifikacije semena u LIZP

are taken into consideration for germination. $\mathrm{Z}$-scores for abnormal seedlings and ungerminated seeds (sum of hard, fresh and dead seeds) are also reported but do not affect the in-round rating. $\mathrm{A}, \mathrm{B}, \mathrm{C}$ and $\mathrm{BMP}$ ratings are given. The in-round rating system for these tests is shown in Table 1.

\section{Results and discussion}

Results for LIZP in this PT round are presented in Table 2. It can be seen that LIZP germination test results were higher than overall mean for all 3 seed lots (L1, L2, L3). The highest difference was in Lot 1 , where percentage of normal seedlings was $84.50 \%$ com-

Table 1. - In-round rating system for germination

Tabela 1. - Sistem ocenjivanja za test klijavosti u okviru jednog kruga

\begin{tabular}{ll}
\hline Score & Sum of absolute $\mathrm{Z}$-scores \\
\hline A & Sum of absolute $\mathrm{Z}$-scores $\leq 3.5$ \\
B & $3.5<$ Sum of absolute $\mathrm{Z}$ values $\leq 5.3$ \\
C & $5.3<$ Sum of absolute $\mathrm{Z}$ values $\leq 7$ \\
BMP & Sum of absolute Z-scores $>7$ \\
\hline
\end{tabular}


pared to $76.85 \%$ overall mean. Percentage of non-germinated seeds was lower in LIZP than overall mean in all three samples. Portion of hard seeds encountered in ungerminated seeds in all three lots were around $10 \%$. Those results indicate that mechanical scarification made seed coat permeable for water and has led hard seeds to germinate. Very important is the fact that mechanical scarification was gentle and hasn't produced abnormal seedlings. Such mechanical scarification could be recommended for application before sowing high dormant seed lots. Many authors have found varieties of Medicago and Trifolium species with high amount of hard seeds (Uzun and Aydin, 2004; Velijević, et al., in press). Although hard seeds are physiologically mature, capable to produce normal seedlings, due to subsequent germination, they cannot withstand the competition with already developed plants and do not contribute in the establishment of forage-leguminous crops (Kimura and Islam, 2012).

Consequently, the applicant should obtain adequate information regarding the number of hard seeds that will appear during seed sowing. This may be the reason for the rare application of scarification in seed testing laboratories revealed in PT 17-2 (Tab. 3).
Among 90 accredited participants, only one more laboratory applied mechanical scarification besides LIZP, 45 laboratories did not use any pre-treatment, and 42 laboratories applied pre-chilling. Regarding applied temperature almost all labs (148) germinated seeds on $20^{\circ} \mathrm{C}$ which is prescribed by ISTA Rules. Another reason for avoiding scarification is a potential risk of damaging seeds in the sample that doesn't have hard seed coat. ISTA Rules (2017) and Handbook on seedling evaluation (Don, 2013) prescribes several pre-treatments for removing hardseededness: soaking, acid and mechanical scarification (piercing, chipping, filing or sandpapering). Sandpapering is aggressive, while piercing and chipping is time consuming. LIZP procedure for scarification can be recommended for use since it is very gentle for seeds and practical for use.

For national and international seed trade regulations differ regarding reporting hard seeds on Report, Declaration vs Orange Certificate. National Regulations (1987) state that hard seeds found in seed testing is added to the percentage of normal seedlings, and this percentage is written on the declaration. For international seed trade hard seeds

Table 2. LIZP germination test results (Proficiency test round 17-2)

Tabela 2. LIZP rezultati testa klijavosti (Proficiency test krug 17-2)

\begin{tabular}{|c|c|c|c|c|c|c|c|c|c|c|c|c|}
\hline & \multicolumn{3}{|c|}{ Normal seedlings } & & \multicolumn{3}{|c|}{ Abnormal seedlings } & \multicolumn{5}{|c|}{ Non-germinated seed } \\
\hline & L1 & $\mathrm{L} 2$ & L3 & & L1 & $\mathrm{L} 2$ & L3 & & L1 & L2 & L3 & \\
\hline LIZP & 84.50 & 84.00 & 88.50 & & 3.50 & 3.25 & 2.50 & & 12.00 & 12.75 & 9.00 & \\
\hline Mean & 76.85 & 79.63 & 83.27 & & 6.18 & 5.18 & 3.90 & & 16.70 & 14.70 & 12.75 & \\
\hline SD & 4.64 & 3.88 & 3.21 & & 2.58 & 1.98 & 1.72 & & 3.50 & 2.93 & 2.94 & \\
\hline Z-scores & 1.65 & 1.13 & 1.63 & 1.47 & -1.04 & -0.97 & -0.81 & -0.94 & -1.34 & -0.67 & -1.28 & -1.09 \\
\hline \multicolumn{6}{|c|}{ Sum of absolute Z-scores for normal seedlings } & 4.40 & & & & & & \\
\hline \multicolumn{6}{|c|}{ LIZP in-round rating for this test round } & B & & & & & & \\
\hline
\end{tabular}


Table 3. Overview of methods used (temperature, substrate and pretreatment) by all participants Tabela 3. Pregled korišćenih metoda (temperatura, supstrat, predtretman) svih učesnika

\begin{tabular}{|c|c|c|c|c|c|c|c|c|}
\hline \multirow{2}{*}{$\begin{array}{c}\text { Temperature } \\
{ }^{\circ} \mathrm{C}\end{array}$} & \multicolumn{2}{|c|}{ Number of users } & \multirow[t]{2}{*}{ Substrate } & \multicolumn{2}{|c|}{ Number of Users } & \multirow[t]{2}{*}{ Pretreatment } & \multicolumn{2}{|c|}{ Number of users } \\
\hline & $\begin{array}{c}\text { Accred. } \\
\text { Labs }\end{array}$ & $\begin{array}{l}\text { Voluntary } \\
\text { Particip. }\end{array}$ & & $\begin{array}{l}\text { Accred. } \\
\text { Labs }\end{array}$ & $\begin{array}{l}\text { Voluntary } \\
\text { Particip. }\end{array}$ & & $\begin{array}{l}\text { Accred. } \\
\text { Labs }\end{array}$ & $\begin{array}{c}\text { Voluntary } \\
\text { Particip. }\end{array}$ \\
\hline 20 & 89 & 59 & PP & 7 & 3 & $\begin{array}{c}\text { No } \\
\text { treatment }\end{array}$ & 45 & 25 \\
\hline $20 \Leftrightarrow 30$ & 1 & 0 & $\mathrm{TP}$ & 65 & 4 & $\mathrm{P}$ & 42 & 24 \\
\hline \multirow[t]{3}{*}{25} & 0 & 1 & BP & 18 & 10 & $\mathrm{PE}$ & 1 & 7 \\
\hline & & & & & & $\mathrm{P}+\mathrm{PE} / \mathrm{Scar}$ & 1 & 2 \\
\hline & & & & & & $\begin{array}{l}\text { Scar., CS, } \\
\text { NO3 }\end{array}$ & 1 & 2 \\
\hline
\end{tabular}

PP - pleated paper; TP - top of paper; BP - between paper; PE - Polyethylene envelope; $\mathrm{P}$ - prechill; Scar. - scarification; CS - cut seeds.

are just reported on the Orange Certificate. This raises the question which information is more adequate for an applicant and seed producer? Laboratory practice is to obtain maximum germination for a seed lot. The objective of ISTA germination test given in 5.1 state: "Laboratory methods have, therefore, been evolved in which the external conditions are controlled to give the most regular, rapid and complete germination for the majority of samples of a particular species." But in the Rule 5.6.3.2 Procedures for removing hardseededness is written:'For many species where hard seeds occur, no attempt is made to germinate them and the percentage found is reported. Where a fuller assessment is required on the request of the customer, some special procedure for removing hardseededness is essential. For this kind of species, a specific amount of hard seeds is taken into account for European certification purposes (ie 20\% for Trifolium repens).

\section{Conclusion}

Mechanical scarification was very efficient in breaking dormancy of white clover by reducing the number of hard seeds in favour of normal seedlings. Procedure for mechanical scarification applied in LIZP is very fast and practical. Nevertheless, this method as well as the method with sandpapering is very rarely used in the laboratories. The reason may be the requirement of the applicant to obtain adequate information regarding the number of hard seeds that will appear during seed sowing. This adequate information is provided in case of international trade (reported on ISTA Orange certificate), but not in the national trade since the percentage of hard seeds is added to the normal seedlings on the Declaration. The use of mechanical scarification could be recommended as a pre-treatment for highly dormant seed lots since it can increase germination potential. 


\section{References}

Baskin CC and Baskin JM, (2014): Seeds: Ecology, Biogeography, and, Evolution of Dormancy and Germination. Second edition, San Diego: Academic Press.

Beković D, Biberdžić M, Stevović V, Stanisavljević R, Stojković S (2008): Uticaj načina setve na prinos i kvalitet semena lucerke. Selekcija i semenarstvo, Vol XIV (1-4): 29-33.

Don R (2013): ISTA Handbook on Seedling Evaluations, 3rd Edition, International Seed Testing Association, Bassersdorf, Switzerland.

Galussi AA and María EM (2017): Anatomical and Chemical Insights into the White Clover (Trifolium repens L.) Seed Coat Associated to Water Permeability, Chapter 10, In: Agricultural and Biological Sciences "Advances in Seed Biology”. pp 188-198. Jose C. Jimen-
ez-Lopez (eds.). InTechOpen Publications, The Argentina.

International Seed Testing Association. International Rules for Seed Testing, edition 2017. ISTA Basserdorf, $\mathrm{CH}$.

Kimura E, Islam MA (2012): Seed Scarification Methods and their use in Forage Legumes. Research Journal of Seed Science, 5(2): 38-50

Uzun F and Aydin I (2004): Improving germination rate of Medicago and Trifolium species. Asian Journal of Plant Sciences, 3(6): 714-717

Velijević N, Simić A, Vučković S, Živanović L, Poštić D, Štrbanović R and Stanisavljević R (2018): Influence of different pre-sowing treatments on seed dormancy breakdown, germination and vigour of red clover and Italian ryegrass. Int. J. Agric. Biol. In press 


\title{
REZULTATI KLIJAVOSTI SEMENA BELE DETELINE U ISTA PROFICIENCY TESTU 17-2
}

\author{
Marija Milivojević, Jasna Kojić, Radmila Vukadinović, \\ Rade Stanisavljević, Dobrivoj Poštić, Tanja Petrović
}

\begin{abstract}
Sažetak
Pojava tvrdog semena kao posledica nepropustljivosti semenjače za vodu je izražena kod vrsta iz familije Fabaceae. Kod divljih biljaka ova osobina je biološki opravdana jer omogućava bolji opstanak, ali za poljoprivredu tvrda semena su nepoželjna jer klijaju sa zakašnjenjem i neravnomerno. Prilikom ispitivanja klijavosti semena ovih vrsta u laboratoriji može se primeniti predtretman (prethodno hlađenje, mehanička skarifikacija) pre naklijavanja u optimalnim uslovima. U ovom radu su prikazani rezultati ispitivanja klijavosti semena Trifolium repens sprovedena u 150 laboratorija širom sveta u okviru Proficiency testa 17-2. Ovi testovi su organizovani od strane Međunarodne organizacije za ispitivanje semena (ISTA), a obavezni su za sve akreditovane laboratorije, jer se na taj način kontroliše kompetentnost osoblja, ispravnost aparata i pouzdanost primenjenih metoda ispitivanja. U avgustu 2017. godine distribuirani su uzorci tri partije semena Trifolium repens. U Laboratoriji za ispitivanje semena u Institutu za kukuruz Zemun Polje (LIZP), ispitana je klijavost u septembru primenom mehaničke skarifikacije i prethodnog hlađenja (2 dana na $5-10^{\circ} \mathrm{C}$ ), a zatim klijanje na $20^{\circ} \mathrm{C}$. Od 90 akreditovanih laboratorija samo je još jedna primenila mehaničku skarifikaciju, 42 laboratorije nisu primenile nikakav predtretman, a 39 laboratorija je primenilo prethodno hlađenje. Dobijeni rezultati klijavosti u LIZP (Lot1$84.50 \%$, Lot2-84\%, Lot3-88.50\%) su bili iznad proseka svih laboratorija (Lot1-76.95\%, Lot279.63\%, Lot3-83.27\%). Kao glavni zaključak ovog Proficiency testa jeste da je skarifikacija semena značajno smanjila broj tvrdih semena u korist normalnih klijanaca. Razlog retke primene skarifikacije može biti potreba korisnika da dobije adekvatnu informaciju vezanu za broj tvrdih semena koja će se pojaviti prilikom setve semena.
\end{abstract}

Ključne reči: Trifolium repens, tvrdo seme, skarifikacija

Primljen: 3.02.2018.

Prihvaćen: 7.03.2018. 